\title{
A EDUCAÇÃO DE JOVENS E ADULTOS NA REGIÃO COSTA VERDE DO ESTADO DO RIO DE JANEIRO ${ }^{*_{1}}$
}

Elionaldo Fernandes Julião ${ }^{2}$

As universidades públicas brasileiras no papel que lhes cabe para o ensino, a pesquisa e a extensão, no período de 2002 até 2015, nos governos do Presidente Lula da Silva e Dilma Rousseff, vinham sendo convocadas a colaborar no âmbito de suas competências na formulação de políticas públicas para a educação brasileira. No âmbito do Ministério da Educação, a Secretaria de Educação Continuada, Alfabetização, Diversidade e Inclusão (SECADI/MEC) ${ }^{3}$, por meio de um processo de diálogo com muitas instituições parceiras, vinha construindo a política pública de Educação de Jovens e Adultos (EJA).

A interlocução do Ministério da Educação (MEC) com as universidades, para a EJA, vinha representando uma inovação no modo de fazer política pública, principalmente reconhecendo a importância da universidade na produção de conhecimento para subsidiar as escolhas de gestores e as práticas pedagógicas nos sistemas de ensino, assim como na formação inicial e continuada de profissionais da educação básica.

A história contemporânea da Educação de Jovens e Adultos (EJA) na política nacional de educação tem como importantes marcos legais e principal ponto de partida, a aprovação da Lei de Diretrizes e Bases da Educação Nacional (Lei 9.394/96 - LDB) e as suas Diretrizes Nacionais Curriculares (Resolu-

${ }^{*}$ DOI - 10.29388/978-65-86678-41-3-0-f.61-94

${ }^{1}$ Este artigo consiste no relatório da pesquisa "Diagnóstico da educação de jovens e adultos na região Costa Verde do estado do Rio de Janeiro: mapeamento do território em subsídio a uma nova agenda política", financiada pela FAPERJ, através do Auxílio à Pesquisa na modalidade Auxílio Instalação (Processo E-26/112.444/2012). A pesquisa contou com a participação dos Pesquisadores: Andreia Cidade Marinho, Cátia Abú, Marcelo André de Souza e Maria Margarida Ferreira.

${ }^{2}$ Doutor em Ciências Sociais. Professor Associado do Instituto de Educação de Angra dos Reis e do Programa de Pós-graduação em Educação da Universidade Federal Fluminense. Coordenador do Grupo de Trabalho e Estudos sobre Políticas de Restrição e Privação de Liberdade da Universidade Federal Fluminense. Vice-coordenador do Núcleo de Estudos e Documentação em Educação de Jovens e Adultos da Universidade Federal Fluminense.

${ }^{3}$ Originariamente a SECADI surge em 2004 apenas como Secretaria de Educação Continuada, Alfabetização e Diversidade, passando a incluir a ideia de inclusão no primeiro governo Dilma. 
ção CNE/CEB no 01/2000) e Operacionais (Resolução CNE/CEB n ${ }^{\circ}$ 03/2010), aprovadas, respectivamente em 2000 e em 2010, pela Câmara de Educação Básica do Conselho Nacional de Educação.

Já como marcos políticos, que se evidencia o espaço ocupado pela EJA na agenda dos governos, podemos destacar a criação, em 2004, da então Secretaria de Educação Continuada, Alfabetização e Diversidade do Ministério da Educação (SECAD); a aprovação do Fundo de Manutenção e Desenvolvimento da Educação Básica e de Valorização dos Profissionais da Educação (FUNDEB), que substituiu o Fundo de Manutenção e Desenvolvimento do Ensino Fundamental e de Valorização dos Profissionais da Educação (FUNDEF) a partir de 2007, incluindo as matrículas da EJA na previsão dos seus recursos; dos Planos Nacionais de Educação de 2001 (Lei no 10.172/2001) e 2014 (Lei 13.005/2014) com metas dedicadas à EJA; e da instituição, em 2007, da proposta de Agenda Territorial de Desenvolvimento Integrado de Alfabetização e de Educação de Jovens e Adultos.

A proposta de constituição de uma Agenda Territorial, segundo Resolução $n^{\circ}$. 65 de 13 de dezembro de 2007, objetivava formular uma ação conjunta do poder público e da sociedade civil em favor da garantia do direito à educação da população jovem e adulta; tornar-se um instrumento para consolidar estratégias de articulação territorial das ações de alfabetização e de Educação de Jovens e Adultos, estruturadas nas dimensões técnica, de planejamento e de controle social; integrar ações do Programa Brasil Alfabetizado e da EJA na definição de uma política pública, a partir do diálogo com os mais diversos parceiros; estabelecer-se, com a indução do MEC, como mecanismo de apoio à estruturação e à institucionalização nos estados, no Distrito Federal e nos municípios, do desenvolvimento integrado de alfabetização e de EJA nos territórios, garantindo a continuidade das aprendizagens dos jovens e adultos, que não se reduzem a processos iniciais de alfabetização.

Como encaminhamento desta proposta política, em junho de 2008, a então SECAD e o Conselho de Secretários de Educação (CONSED) celebraram pacto de compromisso para o desenvolvimento de ações visando à implementação das Agendas estaduais, que incluíram ainda seminários com representantes de Fóruns de EJA de todo o país, em nome da sociedade civil e coordenadores de EJA de estados e de capitais, depois se estendendo, via União Nacional de Dirigentes Municipais de Educação (UNDIME), aos demais coordenadores. Todas as ações tinham como objetivo estabelecer estratégias político educacionais de implantação e/ou fortalecimento da EJA, a partir de um diag- 
nóstico estadual, dos desafios já evidenciados pelas políticas em curso e de recomendações oriundas de diversos espaços formais de discussão.

O MEC vinha desenvolvendo estratégias para implementar a política de Alfabetização e Educação de Jovens e Adultos, principalmente a partir de alguns eixos norteadores, destacando-se: educação continuada, buscando ultrapassar os limites da escolarização formal e valorizar a educação por toda a vida; alfabetização como prioridade política, com foco na cidadania; respeito às diversidades étnica, racial, cultural, de gênero, ambiental, regional e social; abordagem sistêmica; natureza interdisciplinar e transversal: educação e direitos humanos, saúde, cultura, trabalho, meio ambiente; alfabetização articulada com a educação de jovens e adultos. Para atuar nesses eixos, os instrumentos utilizados foram o financiamento; a formação de educadores; investimento na formulação de materiais didáticos; o destaque à importância da leitura literária; e o fortalecimento de redes sociais.

Como estratégias, vinha se valendo da Comissão Nacional de Alfabetização e Educação de Jovens e Adultos (CNAEJA) como organismo assessor consultivo; do diálogo permanente com coordenadores estaduais de EJA e com os Fóruns de EJA; de editais de formação continuada para as Instituições de Ensino Superior; e do Plano de Ações Articuladas (PDE).

Diante dos eixos, das estratégias e dos instrumentos de que a SECAD/MEC vinha lançado mão para a consolidação da Agenda Territorial, cabe destacar o fortalecimento do diálogo entre os poderes públicos e destes com a sociedade civil, no sentido de ampliar e fortalecer a articulação, formulação, execução e acompanhamento das políticas para jovens, adultos e idosos, o que inclui o apoio a processos educativos que favorecessem a produção do conhecimento, a sistematização, a socialização das experiências a partir da realidade local e do respeito à diversidade.

Como membro ativo da Comissão Estadual da Agenda Territorial, as universidades foram convocadas a contribuir como parceira na pesquisa, oferecendo possibilidades constantes de diagnosticar, mapear, intervir e contribuir na formação dos sujeitos envolvidos. No âmbito da formulação da Agenda, e no conjunto de atividades que cabe à Comissão, a ação específica do diagnóstico foi endereçada à universidade.

O diagnóstico, como ação investigativa, dentro da proposta da Agenda, deveria concomitantemente formar gestores pesquisadores em cada território pesquisado, com vista, ao mesmo tempo em que se conheciam a realidade e os saberes sobre os quais se assentam as práticas políticas e pedagógicas, forma- 
rem-se os sujeitos responsáveis pela atuação política na EJA, na crítica às concepções circulantes. Em síntese, deveria constituir a base sobre a qual seria possível consolidar ações articuladas e mais condizentes com as necessidades educativas e educacionais da população jovem e adulta do território.

$\mathrm{Na}$ proposta defendida para o estado do Rio de Janeiro, a universidade executaria a pesquisa na aproximação e abordagem da realidade e, em concomitância, ações técnicas e políticas de formação, assessoramento, disseminação de informações e reconhecimento mútuo das possíveis futuras ações parceiras que municípios e universidades públicas poderiam executar juntas.

Assentou-se na ideia de que o diagnóstico se traduzisse em um mapeamento inicial sobre o território, de um conjunto amplo de práticas de EJA educacionais e educativas, revelando singularidades, necessidades, oferecendo elementos mais adequados à proposição de políticas públicas integradas, favorecendo a circulação dos sujeitos no território, sem perdas ocasionadas pelo desconhecimento das ofertas, qualificando as equipes dos poderes locais quanto aos fazeres indispensáveis na área.

Diante da dificuldade de alcançar os 92 municípios do estado do Rio de Janeiro, com vista a subsidiar políticas públicas integradas, que fortalecessem as necessidades de atendimento à população envolvida — sujeitos de direito, a presente proposta de pesquisa teve como objetivo elaborar um diagnóstico educacional e educativo das ações públicas voltadas a jovens, adultos e idosos, existentes no subterritório Litoral Sul do estado do Rio de Janeiro (Região Costa Verde), que compreende as cidades de Angra dos Reis, Itaguaí, Mangaratiba, Parati e Rio Claro.

Em linhas gerais, em virtude das suas diversas limitações, a pesquisa procurou: (1) mapear as iniciativas educacionais das redes públicas estaduais e municipais voltadas à EJA, nos referidos municípios, identificando alternativas, modos de fazer, concepções, práticas, formas de atendimento, horários, materiais, nomeações etc.; (2) dar subsídios à construção de redes de atores políticos, aproximando instituições e pesquisadores, com vista a otimizar metodologias e procedimentos, no enfrentamento de questões candentes à realidade regional; e (3) ativar processos de formação de graduandos de todas as áreas, pelo exercício de articulação da pesquisa com parceiros locais, no desenvolvimento da investigação.

Levando em conta as prioridades definidas no plano de ação da Comissão Estadual para a Agenda Territorial do Rio de Janeiro, a metodologia da pesquisa, para atender os objetivos fixados, pautou-se na coleta quantitativa de da- 
dos, em primeiro momento, associadamente a modos de abordagem qualitativa, que complementassem as informações inicialmente recolhidas.

Para o trabalho quantitativo, foi previsto a aplicação de um instrumento básico de coleta de informações (questionário) com questões abertas e fechadas visando compreender a organização de cada sistema municipal de ensino. Consistiu na aplicação de um questionário apenas aos gestores de EJA das secretarias municipais de educação.

Já com o objetivo de compreender a dinâmica de implementação da política, a abordagem qualitativa consistiu em entrevistas agendadas com os representantes das secretarias de educação responsáveis pela política de EJA nos municípios em momentos diversos no processo de realização da pesquisa.

Também foram analisados os marcos normativos da EJA nos respectivos municípios, principalmente os documentos aprovados pelas Secretarias e Conselhos Municipais de Educação dos municípios pesquisados.

Posteriormente, foram utilizadas as bases de dados do IBGE, do INEP, principalmente com relação a obtenção dos dados referentes aos censos demográfico e de educação de 2010 a 2015 e Estudos Socioeconômicos dos Municípios do Estado do Rio de Janeiro do Tribunal de Contas do Estado do Rio de Janeiro (2014).

Inicialmente, a proposta de pesquisa se resumia a produzir uma "fotografia” da política implementada na região nos anos de 2011 e 2012. Levando em conta os resultados preliminares dos dados pesquisados, resolvemos ampliar e fazer um estudo de caráter mais longitudinal que possibilitasse um diagnóstico mais aprofundado de um determinado período de desenvolvimento da política no território Sul Fluminense do estado do Rio de Janeiro, principalmente utilizando dados até 2015.

Quando refletimos sobre a educação para jovens e adultos no Brasil, várias questões emergem nesta discussão, principalmente as que envolvem o campo das políticas sociais. É considerado como um tema ainda extremamente relevante e de pouco interesse de estudiosos das diversas áreas do conhecimento, está ainda muito restrito ao campo educação. Geralmente os estudos enfrentam o debate dialogando com questões das áreas de ciências humanas e sociais, principalmente sobre divisão de classes, divisão racial, desemprego, mercado de trabalho, pobreza, desigualdade social, exclusão social, direitos humanos, políticas para juventude, gênero, geração, educação popular, dentre outras.

Embora a política de educação para jovens e adultos não seja um tema absolutamente novo no país, ainda não podemos deixar de prescindir no deba- 
te, implícita ou explicitamente, de recorrer aos aspectos sociais, políticos e ideológicos que envolvem as políticas para as classes populares, principalmente que nos façam refletir sobre as suas contradições.

Neste sentido, ampliando as nossas reflexões sobre o tema na sociedade contemporânea, visando efetivamente avançar na discussão, fundamentado em uma concepção crítica sobre o papel da política de educação implementada para os jovens e adultos das classes populares, temos como objetivo, neste relatório, analisar as suas perspectivas teóricas, políticas e pedagógicas, principalmente dialogando sobre os conceitos garantias de direitos, políticas públicas, diversidade dos sujeitos, território e desenvolvimento.

Em linhas gerais, a partir da análise da experiência de educação implementada para os jovens e adultos da região Costa Verde do estado do Rio de Janeiro, propomos investir na discussão sobre as principais questões que envolvem hoje o tema no Brasil.

Para contribuir com as reflexões e com o debate, como aportes teóricos da pesquisa, dialogamos com pensamentos e estudos de autores de diversas áreas e correntes das ciências humanas e sociais, destacando-se Amartya Sen (2010) sobre desenvolvimento; Renato Ortiz (2015) sobre universalismo e diversidade; e Stephen Ball e Jefferson Mainardes (2011) sobre políticas educacionais; e Richard Sennett (1999) sobre a corrosão do caráter na sociedade contemporânea.

Levando em consideração a proposta da Agenda Territorial, consideramos o conceito território como importante variável de análise. Mais que buscar as características geoecológicas e os recursos naturais de uma certa área, o que se produz ou quem produz em um dado espaço, ou ainda quais as ligações afetivas e de identidade entre um grupo social e seu espaço, importa entender que o território é, além das dimensões geográficas, política, cultura e econômica, um "espaço definido e delimitado por e a partir de relações de poder" (SOUZA, 1995, p. 78-79).

Assim, compreendemos que

[...] o território significa natureza e sociedade; economia, política e cultura; ideia e matéria; identidades e representações; apropriação, dominação e controle; des-continuidades; conexão e redes; domínio e subordinação; degradação e proteção ambiental; terra, formas especiais e relações de poder; diversidade e unidade (...). Cada combinação específica de cada relação espaço-tempo é produto, acompanha e condiciona os fenômenos e processos territoriais (SAQUET, 2013, p. 24). 


\section{Indicadores sociais de educação no atual contexto nacional e flu- minense}

No Brasil, segundo dados divulgados pelo IBGE, em 2012, ainda há 8,6\% da população de 15 anos ou mais analfabetas; 8,1\% de jovens entre 18 e 24 anos frequentando o ensino fundamental, $34,2 \%$ o ensino médio e $51,3 \%$ o ensino superior.

Embora tenham melhorado, os índices ainda nos mantêm na incômoda marca de ser um dos países com a maior taxa de analfabetismo no mundo, es tando à frente de países com menores índices de desenvolvimento humano que o nosso.

Analisando a taxa de analfabetismo do Brasil é possível evidenciar que: $8,8 \%$ é do sexo masculino; $8,4 \%$ é do feminino; $6,5 \%$ possui domicílio urbano e $21,2 \%$ domicílio rural. Distribuídas por região, a maior taxa do país está no nordeste com 16,9\%, seguida, respectivamente, pela norte, com 10,2\%; centrooeste, com 6,3\%; sul, com 4,9\%; e sudeste, com 4,8\%.

Segundo dados do IBGE (2012), o agregado nacional reduziu em 31\% a proporção de pessoas que não sabiam ler nem escrever, passando de 12,1\% em 2001 para 8,6\% em 2011.

De acordo com os dados mais recentes, a maior incidência de analfabetismo ocorre entre homens $(8,8 \%)$, de cor preta ou parda $(11,8 \%)$, com idade acima dos 60 anos $(24,8 \%)$, que pertencem ao quinto mais pobre $(15,1 \%)$, residente da região nordeste $(16,9 \%)$ e das áreas rurais $(21,2 \%)$.

A maior queda no índice de analfabetismo se deu entre os jovens de 15 a 24 anos de idade, cuja taxa passou de $4,2 \%$ para $1,5 \%$ no período considerado. A redução desse índice também foi alta entre as pessoas de 25 a 59 anos de idade (de 11,5\% para 7,0\%).

Esses resultados apontam para o progressivo envelhecimento do perfil do grupo mais afetado pelo analfabetismo. Contudo, isso não significa que a maioria dos analfabetos possui essa faixa etária. Do total de analfabetos de 15 anos ou mais, $50,7 \%$ têm de 25 a 59 anos de idade, representando um montante superior a 6,5 milhões de pessoas.

De fato, este é o grupo mais presente entre aqueles que frequentam curso de alfabetização e educação de jovens e adultos, cuja maioria dos estudantes é mulher $(57,9 \%)$, de cor ou raça preta ou parda $(70,8 \%)$, residente da região nordeste $(50,8 \%)$ e das áreas urbanas $(68,3 \%)$. 
Quanto à média de anos de estudo das pessoas de 15 anos ou mais de idade, a média nacional saltou de 7 anos, em 2001, para 9,6, em 2011. A média da região sudeste é a maior, alcançando 10,1 anos de média para jovens entre 18 e 24 anos. A menor é a da região norte com 8,7 anos, seguida pela região nordeste com 8,8 anos. A região sul possui $10,0 \%$ e a centro-oeste $9,9 \%$.

A taxa de frequência bruta a estabelecimento de ensino da população residente, segundo grupos de idade - Brasil, em 2011, na faixa etária de 6 a 14, alcançou a marca de $98,2 \%$. Por outro lado, na faixa etária entre 15 a 17 anos, ainda é $83,7 \%(2011)^{4}$.

O dado, infelizmente, mostra-nos que embora estejamos quase universalizando o acesso ao ensino fundamental de crianças na faixa etária de 6 a 14 anos, ainda amargamos o resultado de um grande número de jovens que, por problemas de retenção e evasão, não se mantém estudando.

Como consequência do atraso escolar, cerca de metade dos jovens estudantes de 18 a 24 anos de idade, que já deveriam ter completado sua trajetória escolar na educação básica e ingressado na universidade, não cursavam este nível educacional. Ocorreu uma queda expressiva na proporção desses jovens que ainda cursavam o ensino fundamental no período de 2001 a 2011, passando de $21 \%$ para $8 \%$. A frequência desses estudantes no ensino superior também evoluiu positivamente, aumentando de $27 \%$ para $51 \%$ no período. Esses resultados evidenciam os efeitos da expansão educacional, mas importantes disparidades podem ainda ser observadas.

A proporção de jovens estudantes brancos de 18 a 24 anos de idade, por exemplo, que frequentavam o ensino médio diminuiu em função da elevação da frequência líquida. Em contrapartida, os jovens estudantes pretos ou pardos na mesma faixa etária mantêm a frequência nesse nível. Isso é uma evidência de que o crescimento substancial na frequência líquida dos estudantes de cor ou raça preta ou parda no ensino médio não foi suficiente para reverter os efeitos do atraso escolar desse grupo ao longo dos últimos dez anos. O aumento da frequência observada para os jovens pretos ou pardos no ensino superior também não foi suficiente para alcançar a mesma proporção apresentada pelos jovens brancos dez anos antes.

$\mathrm{Na}$ análise da média de anos de estudo por quintos do rendimento familiar per capita, mesmo na faixa etária de maior escolaridade (18 a 24 anos de idade), percebe-se que as desigualdades escolares ainda persistem e são significativas.

\footnotetext{
${ }^{4}$ Saiu de $81,1 \%$ (2001).
} 
A proporção de jovens de 18 a 24 anos de idade que possuíam 11 anos ou mais de estudo completo aumentou substancialmente, passando de 33,7\% para 54,1\% em dez anos.

Em 2011, 61\% das mulheres de 18 a 24 anos de idade possuíam ensino médio completo ou mais, enquanto esse indicador era de $48 \%$ para os homens. Entretanto, importantes diferenças entre as mulheres devem ser ressaltadas. $\mathrm{O}$ hiato dessa proporção entre homens e mulheres (13 pontos percentuais) é menor do que aquele encontrado entre mulheres brancas e mulheres pretas ou pardas (18 pontos percentuais). Isso significa que cerca de metade das mulheres pretas ou pardas possuíam o ensino médio completo em comparação com $71 \%$ das mulheres brancas para esse ano.

Gráfico 1: Censo escolar Educação de Jovens e Adultos - dados nacionais (2010 a 2015)

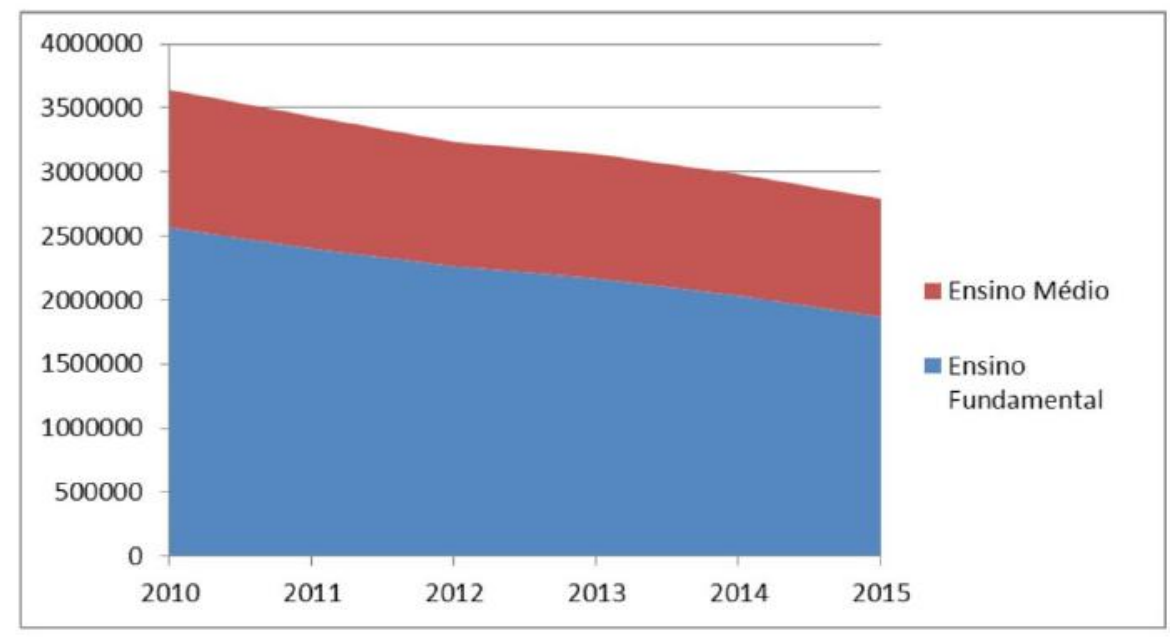

Fonte: INEP (2013, 2014, 2015)

O Censo Escolar 2015 indica que 2.792 .758 estudantes estavam matriculados na educação de jovens e adultos nas redes públicas estaduais e municipais de ensino no Brasil. Deste total, 66,93\% (1.869.426) estavam no ensino fundamental e 33,07\% (923.332) no ensino médio.

Desde 2008, o país vem vivenciando um decréscimo no número de matrículas na EJA. Só em 2015, a redução foi 9,48\% (sendo 8,18\% do EF e $2,72 \%$ do EM) em comparação com os dados de 2014, quando foram registradas 3.085.304. Em 2014, a redução foi de 4,97\% em comparação a 2013, que ti- 
nha 3.141.566 matrículas e já computava uma redução de 2,95\% (sendo 4,2\% do EF e 0,04\% do EM) em comparação com os dados de 2012, quando foram registradas 3.237.333.

Em 2012, o Brasil registrava uma redução de matrículas de 5,74\% (sendo 5,67\% do EF e 5,9\% do EM) em comparação a 2011 que era 3.434 .567 e já computava uma redução de 5,70\% (sendo 6,39\% do EF e 4,07\% do EM) em relação a 2010 com 3.642.513.

Um dado fundamental que deve ser levado em consideração na discussão destes números é que a considerável diminuição no quantitativo de matrículas da EJA vem acompanhado da mudança do perfil dos sujeitos demandantes. Ao contrário do que geralmente acontecia décadas atrás, em que o público da EJA era majoritariamente de jovens e adultos que não tinham acesso aos bancos escolares, hoje, cresce o número dos que tiveram acesso à escola, porém, por motivos diversos não conseguiram permanecer nela.

Conforme Marinho (2015, p. 35), “ultimamente, o crescimento do número de jovens a partir dos 14 ou 15 anos na educação de jovens e adultos tem sido anunciada e discutida". Acreditava-se que com a universalização do ensino fundamental para as crianças a partir dos 6 anos de idade diminuiria consideravelmente o público da EJA, principalmente restringindo a modalidade da educação básica para os mais velhos que não tiveram oportunidade de estudar anteriormente. Infelizmente, como evidenciado acima, não é o que efetivamente vem acontecendo. Ao contrário, cresce o número de jovens que estiveram na escola, mas que, por diversas questões, acabaram migrando a partir dos 15 anos para a EJA.

Como podemos evidenciar, a demanda atual por escolarização na EJA ainda é muito grande. Ao contrário do que se pode imaginar, a redução do número de matrículas não está relacionada com a diminuição do número de jovens e adultos que necessitam desta política.

A Pesquisa Nacional por Amostragem dos Domicílios (PNAD), realizada pelo IBGE em 2009, aponta diversos fatores que podem justificar essa situação, destacando-se: a falta de infraestrutura dos espaços escolares para atender as demandas dos alunos jovens e adultos; de formação inicial dos professores que atuam nesta modalidade; de oferta da EJA em horários alternativos (diurno) - para atender os alunos trabalhadores e as mães que não tem com quem deixar os seus filhos; de articulação entre a EJA e o mundo do trabalho; do não reconhecimento da diversidade dos sujeitos da EJA etc. 
Nos últimos anos, o número de jovens com distorção idade série na educação básica tem alarmado os sistemas de ensino no país que tem entre as suas causas principais o alto índice de reprovação e abandono escolar, motivadas, tanto por fatores internos (que envolvem a dimensão ensino-aprendizagem e a gestão pedagógica), quanto por fatores externos (relacionados às questões econômicas, políticas e sociais) que influenciam todo o sistema educacional. Segundo os relatórios anuais do censo escolar brasileiro, a defasagem idade série é um fato presente em toda rede pública de ensino, causada, principalmente, pelo grande número de reprovação e evasão escolar. Em 2009, segundos dados do INEP, 20\% dos alunos matriculados da educação básica estavam com distorção idade série. Em 2014 caiu para 14\%, destes 27\% estão nas séries finais do ensino fundamental e $28 \%$ no ensino médio.

Levando em conta que a distorção idade série compromete o Índice de Desenvolvimento da Educação Básica (IDEB) ${ }^{5}$ dos estados, a educação de jovens e adultos tem sido reconhecida pelos governos como uma mera estratégia de correção de fluxo, transferindo quase que automaticamente os jovens que completam 15 anos para a modalidade de EJA ou criando Projetos específicos de aceleração de aprendizagem.

No estado do Rio de Janeiro, por exemplo, que em 2007 apresentava uma taxa de distorção idade série de 39\% para o Ensino Fundamental e 53,1\% para o Ensino Médio, a Secretaria de Estado de Educação criou, em 2009, o Projeto Autonomia, em parceria com a Fundação Roberto Marinho, com o objetivo de promover a aceleração de aprendizagem e a correção da distorção idade série de alunos do segundo segmento do ensino fundamental ( $6^{\circ}$ ao $9^{\circ}$ anos $)$ e ensino médio da rede pública de ensino por meio da organização curricular em módulos, unidocencia ${ }^{6}$ e de telessalas, concluindo o ensino fundamental em

\footnotetext{
${ }^{5}$ O Ministério da Educação criou em 2007 o Índice de Desenvolvimento da Educação (IDEB), que visa conferir as metas de qualidade de ensino. É feito uma média entre a aprovação e o rendimento em Língua Portuguesa e Matemática. O índice de aprovação é obtido por meio do censo escolar e a verificação de conteúdo é aferida através das avaliações organizadas e coordenadas em nível do Sistema de Avaliação da Educação Básica (SAEB), realizada pelo Instituto Nacional de Pesquisas Educacionais Anísio Teixeira (INEP)/MEC. O SAEB é composto pela Prova Brasil, aplicada aos alunos do $5^{\circ}$ ano e $9^{\circ}$ ano do Ensino Fundamental, e pelo SAEB, aplicada aos alunos do $3^{\circ}$ ano do Ensino Médio. O objetivo destas avaliações, segundo o governo federal, é identificar as regiões/municípios em que o ensino está deficiente e os aspectos desta deficiência para, então, criar políticas públicas que venha ajudar municípios e escolas a superar tais dificuldades e, assim, efetivar um ensino de qualidade em todo território nacional.

${ }^{6}$ Existência de um único professor para lecionar todas as disciplinas da matriz curricular, com exceção de Educação Física, visto que o Conselho Regional de Educação Física (CREF) conseguiu em juízo impedir que as aulas desta disciplina sejam ministradas por profissionais sem formação acadêmica em Educação Física e sem registro no referido órgão.
} 
apenas 12 meses.

Os resultados foram evidenciados nos anos subsequentes quando o estado do Rio de Janeiro saiu da vigésima sexta posição no ranking do IDEB dos estados brasileiros, em 2009, no ensino médio, para o quarto lugar, em 2013.

Gráfico 2: Censo escolar educação de jovens e adultos - dados do estado do Rio de Janeiro (2010 a 2015)

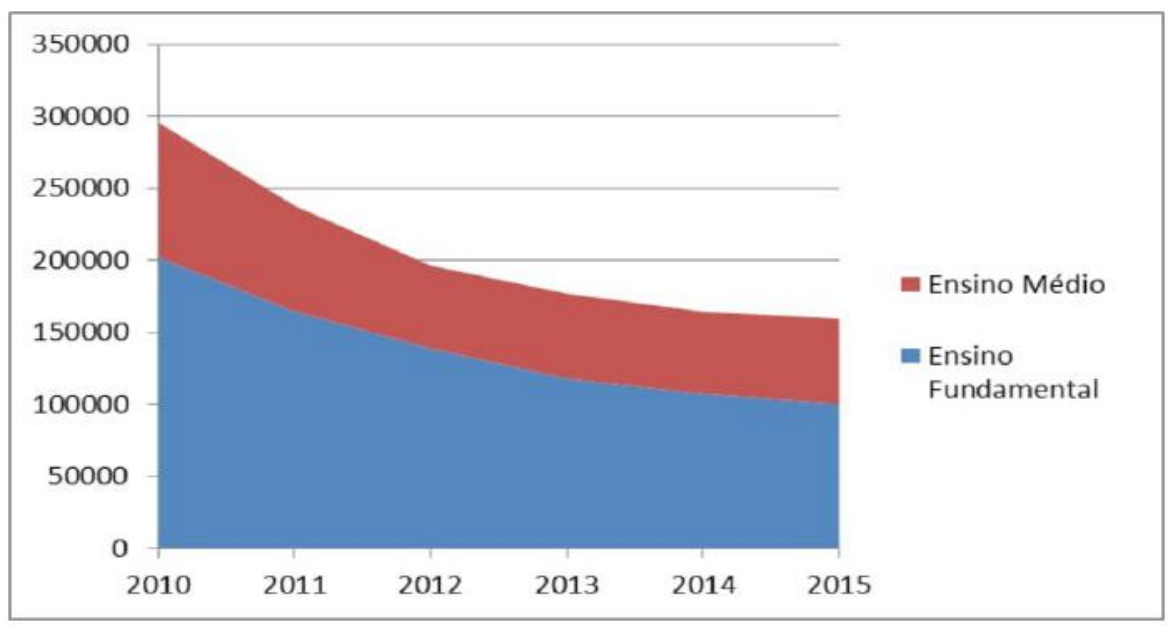

Fonte: INEP $(2013,2014,2015)$

O Censo Escolar 2015 indica que 159.727 estudantes estavam matriculados na educação de jovens e adultos nas redes públicas estadual e municipais de ensino no Rio de Janeiro. Deste total, 62,85\% (100.400) estavam no ensino fundamental e $37,14 \%$ (59.327) no ensino médio.

O estado do Rio de Janeiro, assim como todo o Brasil, vem vivenciando um decréscimo no número de matrículas na EJA. Só em 2015, a redução foi 2,94\% em comparação com os dados de 2014, quando foram registradas 164.5817. Em 2014, a redução foi de 7,07\% (sendo 8,9\% do EF e 3,37\% do EM) em comparação a 2013, que tinha 177.117 matrículas e já computava uma redução de $9,86 \%^{8}$ em comparação com os dados de 2012 , quando foram registradas 196.496.

\footnotetext{
${ }^{7}$ A redução de matrículas no Ensino Fundamental no estado foi de 6,67\%. O aumento de matrículas no Ensino Médio de 4,08\% amorteceu a redução geral.

${ }^{8}$ A redução de matrículas no Ensino Fundamental no estado foi de 15,05\%. O aumento de matrículas no Ensino Médio de 2,7\% amorteceu a redução geral.
} 
O estado já registrava, em 2012, uma redução de 17,47\% das suas matrículas (sendo 15,60\% do EF e 21,66\% do EM) em comparação com os dados de 2011, que era de 238.095 e também já computava uma redução de 19,51\% (sendo $18,57 \%$ do EF e $21,56 \%$ do EM) em comparação com os dados de 2010, quando foram registrados 295.836 .

Em 2013, a Secretaria de Estado de Educação (SEEDUC), em parceria com a Fundação Centro de Ciências e Educação Superior à Distância do Estado do Rio de Janeiro (CECIERJ), implantou em todas as escolas que ofertam EJA no Ensino Médio o Programa Nova Educação de Jovens e Adultos (Nova EJA).

Segundo o Relatório da SEEDUC (2014), em 2013, com esta nova proposta, houve um crescimento de escolas ofertando a EJA, passando de 574, em 2012, para 634, em 2013.

O aumento do número efetivo de escolas ofertando EJA no estado, por outro lado, não correspondeu diretamente a um crescimento do número de alunos matriculados nesta modalidade de ensino. Em 2011, a rede possuía $210.789^{\circ}$ e, em 2013, reduziu 33,95\%, caindo para 139.234 alunos, destes 69.738 $(50,1 \%)$ estavam na modalidade semipresencial ${ }^{10}$ (RIO DE JANEIRO, 2012; 2013; 2014).

Quanto à distribuição das matrículas da EJA no estado do Rio de Janeiro em 2014, segundo a Secretaria de Estado de Educação, há maior participação das fases 8 e 9 (juntas são 71\% das matrículas da etapa, em 2012 era 65\%). No Ensino Médio, as matrículas que estavam bem distribuídas entre as séries (variando entre $31 \%$ e $35 \%$ nas fases 1,2 e 3) apresentaram uma leve concentração na fase $2(40 \%)$ (RIO DE JANEIRO, 2014).

Através da análise dos marcos legais e operacionais da EJA nas últimas décadas, é possível evidenciar avanços e retrocessos na política implementada. Em um enorme descompasso entre os marcos, podemos afirmar que conquistamos importantes normativas que regulamentam a execução da política. Porém, por outro lado, não foi efetivado na prática. Em síntese, os avanços legais não corresponderam efetivamente em conquistas na consolidação da política de EJA. Além da redução de matrículas, discute-se a qualidade do ensino ofertado no país.

${ }^{9}$ Os dados não fazem distinção entre matrículas presencial e semipresencial. Neste ano a Secretaria ainda contabilizava o número de matrículas do Projeto Autonomia separado do regular, possuindo 15.209 alunos.

${ }^{10}$ A SEEDUC reconhece as matrículas desta modalidade como EJA integral. Segundo ela, esta "categorização explica-se pelo fato de que a escola/professores está disponível em período integral aos alunos matriculados nesta modalidade" (RIO DE JANEIRO, 2014, p. 24). 


\section{Aspectos políticos, econômicos e sociais da região Costa Verde do estado do Rio de Janeiro}

Diversas são as questões que envolvem a definição da Região da Costa Verde no estado do Rio de Janeiro. Para efeitos de divulgação turística, por exemplo, a região compreende todo o território litorâneo que banha os municípios de Mangaratiba, Angra dos Reis, Itaguaí e Parati (no estado do Rio de Janeiro) e Ubatuba, Caraguatatuba, São Sebastião e Ilhabela (no estado de São Paulo).

Visando a organização, o planejamento e a execução de funções públicas e serviços de interesse comum, através da Lei estadual $n^{\circ} 1.227 / 87$, que aprovou o Plano de Desenvolvimento Econômico e Social 1988/1991, o estado do Rio de Janeiro está dividido em oito Regiões de Governo: Metropolitana, Noroeste Fluminense, Norte Fluminense, Baixadas Litorâneas, Serrana, CentroSul Fluminense, Médio Paraíba e Costa Verde.

Desde então, foram feitas algumas alterações tanto na denominação quanto na composição dessas Regiões. Conforme a Lei complementar $n^{\circ} 105$, de 04 de julho de 2002, art.12, por exemplo, "fica instituída a Região da Costa Verde, composta dos Municípios de Itaguaí, Mangaratiba, Angra dos Reis e Parati, com vistas à organização, ao planejamento e à execução de funções públicas e serviços de interesse comum" (Rio de Janeiro, 2002).

Reconhecendo particularidades no bloco, segundo o seu Parágrafo único, "a Região da Costa Verde é dividida em duas Microrregiões, a saber: I - Microrregião da Baía de Sepetiba integrada pelos Municípios de Itaguaí e Mangaratiba, e II - Microrregião da Baía da Ilha Grande, integrada pelos Municípios de Angra dos Reis e Parati”. (Rio de Janeiro, 2002)

Enquanto a Microrregião da Baía de Sepetiba está mais ligada à Região Metropolitana, a Microrregião da Baía da Ilha Grande se favorece, em função das inúmeras praias e ilhas e da presença da Mata Atlântica ainda preservada, com o desenvolvimento do turismo que alavanca o setor terciário da economia.

Em 2009, através da Lei Complementar n 130, de 21 de outubro de 2009, art. 12, a Região Costa Verde passa a ser composta apenas pelos municípios de Mangaratiba (Microrregião da Baía de Sepetiba), Angra dos Reis e Parati (Microrregião da Baía da Ilha Grande). O município de Itaguaí, conforme o art. $1^{\circ}$, passa a integrar a Região Metropolitana do estado. 
Para efeito desta pesquisa, consideramos fazendo parte da Região Costa Verde os municípios de Itaguaí, Mangaratiba, Angra dos Reis, Parati e Rio Claro, todos municípios do Rio de Janeiro cortados pela Rodovia Rio-Santos.

Figura 1: Mapa da Região Costa Verde do estado do Rio de Janeiro

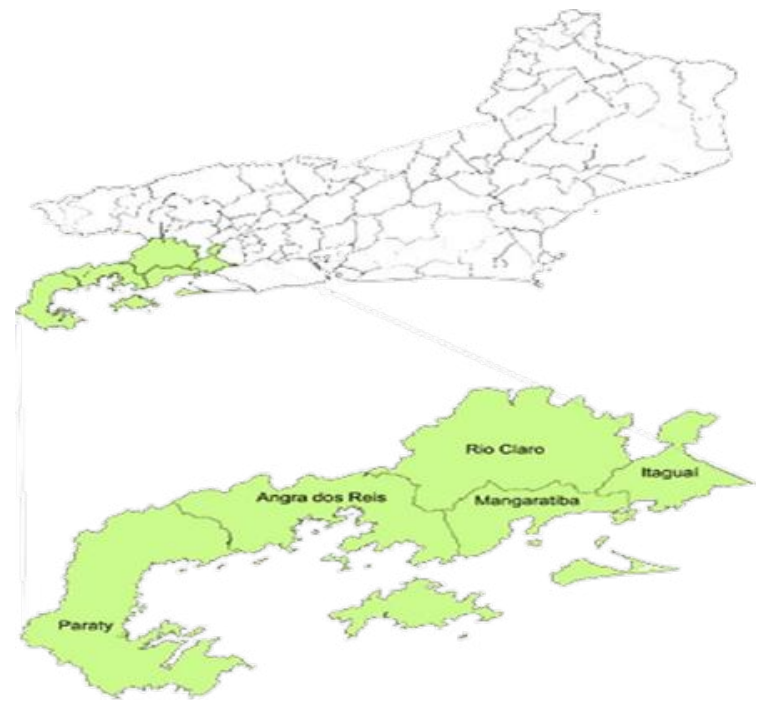

É importante salientar que ao longo da sua história, principalmente com a implantação da indústria de construção naval e a abertura da Rodovia Rio-Santos, toda essa região vem sofrendo grandes modificações, não só ambientais como sociais e econômicas. Neste sentido, torna-se fundamental compreender cada município particularmente, principalmente visualizando a sua participação política, econômica e social na região.

Através dos dados disponíveis no Censo de 2010 do Instituto Brasileiro de Geografia e Estatística - IBGE, foi possível realizar um diagnóstico da população da Região Costa Verde do estado do Rio de Janeiro, principalmente levando em conta os dados relativos à idade, sexo, cor, renda, religião, nacionalidade, naturalidade e educação.

Conforme dados da população total dos municípios, a Região Costa Verde possuía uma população de 370.016 habitantes distribuídos em um território de 3.212,684 km². Com uma densidade demográfica de 153,9, a população de Angra dos Reis corresponde 45,81\% deste total, seguido por Itaguaí com $24,48 \%$, Parati com 10,14\%, Mangaratiba com 9,85\% e Rio Claro com 4,7\%. 
Com um Produto Interno Bruto (PIB) de R \$ 153.502.002,50, a renda per capta da região é $\mathrm{R} \$ 505,56$. Angra dos Reis possui o maior PIB da região, $\mathrm{R} \$$ 60.119.000,62, enquanto Rio Claro o menor com $\mathrm{R} \$ 11.408 .000,51$. Por outro lado, a maior renda per capta é de Mangaratiba com $\mathrm{R} \$ 709,95$ e a menor é de Angra dos com Reis R \$354,66.

Quanto à população residente, $92,17 \%$ estão em situação urbana de domicílio. Os municípios com maior número de residências em situação rural são Parati, com 26\%, seguido de Rio Claro, com 21\% e Mangaratiba, com 12\%. Já os municípios com os menores são Angra dos Reis com 4\% e Itaguaí com 5\%.

Com relação à distribuição da população por faixa etária, 30.986 (8,37\%) estão na faixa de 0 a 5 anos; 58.593 (15,83\%) entre 6 e 14 anos; $126.395(34,15 \%)$ entre 15 e 29 anos; $150.590(40,69 \%)$ entre 30 e 59 anos; e $34.731(9,38 \%)$ acima de 60 anos.

Como podemos evidenciar, a maior parte da população na região está na faixa etária economicamente ativa (15 a 59 anos) - 74,84\%.

Com exceção de Mangaratiba, que o número de mulheres é um pouco maior que o de homens, $50,72 \%$, nos demais municípios da região, o número de homens é um pouco superior.

Com relação à cor ou raça, $47,22 \%$ da população da Região é branca; $42,86 \%$ é parda; $8,58 \%$ preta; $1,07 \%$ amarela; e $0,25 \%$ indígena.

Quando comparado os referidos dados nos municípios, o maior número de indivíduos da população branca está em Rio Claro com 58\%, seguido por Angra dos Reis com 51\%, Parati com 50\%, Mangaratiba, 44\% e Itaguaí, 39\%. Já a população parda, Itaguaí possui o maior número, $50 \%$, seguido por Mangaratiba com 47\%, Parati com 41\%, Angra dos Reis com 39\% e Rio Claro com $31 \%$.

A maior concentração de população preta está em Itaguaí e Rio Claro com 10\% cada, seguida por Mangaratiba com 9\%, Angra dos Reis com 8\% e Parati com $7 \%$.

Em ambos municípios se encontra uma pequena população indígena. O maior número está em Angra dos Reis com 501 indivíduos, seguido por Parati com 246 e Itaguaí com 149. Os menores números estão em Rio Claro com 3 indivíduos e Mangaratiba com 29.

Com relação ao rendimento nominal mensal da população da região acima de 10 anos, de um total de 164.651 pessoas, somente 5.238 (3,18\%) declararam sem rendimentos; $43.881(26,65 \%)$ declararam receber até um salário mínimo; 60.038 (36,46\%) mais de 1 a 2 salários; 23.956 (14,54\%) de 2 a 3 salá- 
rios mínimos; 18.397 (11,17\%) de 3 a 5 salários; 9.880 (6\%) de 5 a 10 salários; $2.553(1,55 \%)$ de 10 a 20 salários e $708(0,43 \%)$ acima de 20 salários mínimos.

Com relação as pessoas em condições de atividades a partir de 15 anos de idade, $180.627(51,42 \%)$ declararam economicamente ativas e 134.593 (38,32\%) não economicamente ativas.

Quanto à distribuição da população da região por religião, 143.501 (38,78\%) se declaram católicas, 132.662 (35,85\%) evangélicos e 6.772 (1,83\%) espíritas.

Com exceção de Itaguaí, que possui $55 \%$ de evangélicos ${ }^{11}$, predomina a religião católica nos demais municípios. O município com o maior número de católicos é Parati com 58\% seguido por Rio Claro e Mangaratiba com 55\% cada e Angra dos Reis com 53\%.

A presença da comunidade espírita na região é representada por $4 \% \mathrm{em}$ Angra dos Reis e Rio Claro, e 2\% nos demais municípios.

Quanto à população residente por nacionalidade na região, 368.666 $(99,63 \%)$ são brasileiros natos, 225 indivíduos são brasileiros naturalizados e 1.124 são estrangeiros.

Dos brasileiros natos, $62,62 \%$ são naturais dos seus respectivos municípios e 17,59\% são naturais de outras unidades da federação. Embora seja grande o número de imigrantes, ele não é o que se imaginava e geralmente é divulgado na região. Predomina o número de uma população natural dos seus municípios.

Quanto à escolarização da população, 30,44\% frequentam a creche ou escola, em 2010, e 8,66\% nunca frequentou creche ou escola. Parati e Rio Claro são os municípios com o maior número de pessoas que nunca frequentaram creche ou escola, $12 \%$ e $11 \%$, respectivamente.

Levando em conta que o público da modalidade de ensino Educação de Jovens e Adultos é a partir de 15 anos de idade, a região ainda tem uma população de 15.908 de analfabetos e 14.255 pessoas que nunca frequentaram creche ou escola, nesta faixa etária.

${ }^{11}$ Seguido por Angra dos Reis com 45\%, Mangaratiba e Rio Claro com 41\% cada, e Parati com $40 \%$. 
Tabela 1: População residente nos municípios da Região da Costa Verde por frequência escolar

\begin{tabular}{lcccc}
\hline MUNICÍPIOS & População & $\begin{array}{c}\text { Frequenta a creche ou } \\
\text { escola }\end{array}$ & $\begin{array}{c}\text { Nunca frequentou a } \\
\text { creche ou escola }\end{array}$ & $\begin{array}{c}\text { Acima de 15 anos } \\
\text { Residente que } \\
\text { nunca frequentou } \\
\text { a creche ou escola }\end{array}$ \\
\hline Angra & 169.511 & 53.526 & 13.707 & 5.958 \\
Itaguaí & 109.091 & 32.931 & 9.477 & 3.985 \\
Mangaratiba & 36.456 & 10.637 & 2.660 & 1.375 \\
Parati & 37.533 & 10.723 & 4.364 & 1.815 \\
Rio Claro & 17.425 & 4.826 & 1.858 & 1.122 \\
\hline TOTAL & 370.016 & 112.643 & 32.066 & 14.255 \\
\hline
\end{tabular}

Fonte: IBGE, 2010.

\section{A Educação de Jovens e Adultos na Região Costa Verde}

Através da aplicação de questionários em 2011/2012, foram solicitadas informações aos coordenadores de Educação de Jovens e Adultos dos cinco municípios pesquisados sobre os marcos normativos da EJA; sobre a quantidade de unidades escolares existentes no município; assim como número de professores e seus perfis; sobre financiamento e recursos para a EJA; espaço físico; gestão administrativa e pedagógica; organização pedagógica e curricular; projeto político pedagógico; material didático; e sobre o perfil das turmas e número de alunos (matriculados, concluintes, evadidos etc.).

Os dados apresentados referem-se às respostas dos municípios pesquisados tanto ao questionário como as entrevistas realizadas ao longo do processo.

A experiência de EJA na Região é bastante diversa. Com exceção de Angra dos Reis e Parati que iniciaram as suas experiências a partir de 1990, Itaguaí iniciou em 1997 e Mangaratiba em 2010. Infelizmente, Rio Claro não respondeu à questão.

A experiência de Angra dos Reis se inicia em 1990 como "Regular Noturno", somente a partir de 2007 é que passou a seguir a proposta como modalidade de ensino prevista na Lei de Diretrizes e Bases da Educação (Lei 9394/96). Praticamente a proposta diurna era aplicada à noite. O diferencial do Projeto Noturno, segundo a coordenação de EJA, era a comissão de docentes, gestores e alunos, que promovia movimento democrático de escuta e escrita, visando uma prática diferenciada para esse público. 
Por algum tempo, paralelamente ao Regular Noturno, o município desenvolveu a alfabetização de adultos através do Movimento de Alfabetização de Jovens e Adultos (MOVA) e de outras parcerias.

Já Mangaratiba, antes de 2010, funcionava como Ensino Fundamental Noturno Acelerado.

Parati e Itaguaí possuem experiências com alfabetização e elevação de escolaridade no primeiro e segundo segmentos do ensino fundamental. Rio Claro somente com o primeiro segmento do ensino fundamental. Já Mangaratiba, além destas experiências, seguindo a proposta do antigo Centro de Ensino Supletivo da Secretaria de Estado de Educação, também possui turmas de Ensino Médio semipresencial.

Angra dos Reis, além da alfabetização e turmas de primeiro e segundo segmentos do ensino fundamental, já teve experiência com o Programa Nacional de Inclusão de Jovens (PROJOVEM) e com um curso de informática e qualificação profissional oferecidos pela Secretaria de Educação através da Gerência de Ciência e Tecnologia chamado TECLAR, além de projetos como a EJA Guarani e Educação para os jovens e adultos ribeirinhas.

Dois dos municípios da região Costa Verde pesquisados foram condecorados coma medalha Paulo Freire ${ }^{12}$ : Mangaratiba (em 2010) com o seu "Projeto Relendo o mundo pelas lentes da educação" (Escola Municipal do Batatal (Zona Rural)) e Angra dos Reis (em 2011), com o seu projeto de Educação de Jovens e Adultos para a tribo indígena Guarani.

A proposta pedagógica de alfabetização promovida por Parati, Itaguaí e Mangaratiba são de 1 ano e a de Angra dos Reis é de 2 anos.

Já a proposta pedagógica para as séries iniciais do ensino fundamental, com exceção de Rio Claro, que é de 2 anos e meio, são promovidas por todos em 2 anos. Para as séries finais, todas são de 2 anos.

O município de Angra dos Reis possui duas unidades escolares que atuam com a EJA no período anual, com duração de 8 anos para o ensino fundamental.

Mangaratiba possui uma experiência com a EJA semipresencial tanto para o ensino fundamental como para o ensino médio, cujo tempo para a sua integralização depende de cada aluno, visto que os estudos são através de módulos/disciplinas.

\footnotetext{
${ }^{12}$ Prêmio concedido pelo Ministério da Educação através da Secretaria de Educação Continuada, Alfabetização, Diversidade e Inclusão desde 2005 para reconhecidas experiências educacionais de educação de jovens e adultos no Brasil.
} 
Com relação ao financiamento da EJA, com exceção de Rio Claro, que não respondeu esta questão, todos possuem financiamento para as ações de EJA através de recursos dos governos federal, estadual e municipal.

Quanto a sua organização pedagógica, o horário de funcionamento da EJA, com exceção de Rio Claro, que possui uma classe de Educação Especial no horário da tarde, todas as experiências na região estão concentradas no horário noturno de 18 às 22 horas.

Com exceção de Itaguaí, que não respondeu à pergunta, todos os municípios possuem Projeto Político Pedagógico (PPP).

Rio Claro informou que o seu projeto foi construído pela direção da escola, pedagogos e comunidade escolar. Parati informou que foi construído pelos docentes e equipe pedagógica que atua na unidade escolar. O de Mangaratiba foi construído por toda a comunidade escolar e Angra dos Reis informou que "a formulação do projeto político pedagógico é um processo que envolve a comunidade escolar e deve ser organizado ou coordenado pela equipe gestora de cada unidade". Segundo a sua coordenação, "não existe um movimento por parte da coordenação para a elaboração do PPP específico para EJA e sim, uma articulação da unidade escolar, envolvendo todos os níveis e modalidades de ensino (educação infantil, ensino fundamental, educação especial e EJA)".

Sobre a equipe de gestão para EJA, Mangaratiba informou que somente em algumas unidades escolares possuem além do diretor, 1 coordenador pedagógico e 1 orientador educacional.

Rio Claro informou que não possui, mas que será realizada, posteriormente, pela Divisão de EJA ${ }^{13}$.

Já Itaguaí informou que a equipe de gestão da escola é a mesma para os três turnos. Em Parati, na unidade escolar que atua com EJA, existe uma equipe específica formada por 1 diretor, 1 coordenador dos anos iniciais e 1 coordenador dos anos finais do ensino fundamental.

Já em Angra dos Reis, o regime do município assegura para as escolas com 3 turnos o direito a ter 1 auxiliar de direção específico para o turno; as secretarias de escolas contam com, pelo menos, 1 funcionário no horário noturno; e os pedagogos são lotados nas unidades de ensino atuando nos três turnos.

Com exceção de Angra dos Reis e Itaguaí (que não responderam à pergunta), os demais municípios informaram que as unidades escolares não possuem autonomia administrativa e financeira.

${ }^{13}$ Deveria ser criada em 2013. 
Sobre o material didático específico para EJA, Itaguaí informou que não possui e utiliza os livros didáticos propostos e encaminhados pelo MEC. Parati trabalha com apostilas produzidas pelos professores, adaptadas de acordo com o planejamento e a duração do curso. Mangaratiba utiliza somente os materiais que estão disponíveis no site do MEC, como a Coleção Cadernos da EJA, "Viver e Aprender", além dos materiais produzidos pelos próprios professores. Rio Claro não respondeu à pergunta.

Segundo Angra dos Reis, na Secretaria de Educação existe um setor específico para atendimento as bibliotecas escolares, garantindo a aquisição de livros paradidáticos e assessoramento, quando necessário, na compra de livros realizada pela própria unidade escolar, mediante verba do recurso direto para a escola. Informou ainda que as Unidades Escolares tem autonomia para utilizar e elaborar material didático diversificado como, por exemplo, apostilas mais adequadas às suas necessidades.

Em 2007 e 2008, em parceria com a instituição GRHUBAS Projetos Culturais e Educativos, foi elaborado um livro didático específico para a I Etapa da EJA. A partir de 2010, a prefeitura recebeu os livros didáticos do Programa Nacional de Distribuição de Livro Didático para a EJA (PNDL/EJA). Em parceria com a Secretaria de Estado de Educação do Rio de Janeiro, através da sua reserva técnica, a prefeitura tem adquirido livros didáticos para os alunos e acervos para as bibliotecas.

De acordo com os dados do Censo Escolar de 2014, publicados no Diário Oficial da União no dia 9 de janeiro de 2015, na região Costa Verde existiam 19 escolas estaduais com turmas de educação de jovens e adultos, sendo: 7 em Angra dos Reis, 6 em Itaguaí, 3 em Rio Claro, 2 em Mangaratiba e 1 em Parati.

Em Angra dos Reis, estavam matriculados 1.673 alunos nas escolas estaduais, sendo 409 nos anos finais do ensino fundamental e 722 no ensino médio na modalidade semipresencial e 542 no ensino médio presencial. Em Itaguaí estavam matriculados 1.096 alunos, sendo: 158 nos anos finais do ensino fundamental e 220 no ensino médio na modalidade presencial; e 202 nos anos finais do ensino fundamental e 516 no ensino médio na modalidade semipresencial.

Em Mangaratiba, 219 alunos estavam matriculados no ensino médio na modalidade presencial e Parati 77 alunos no ensino médio na modalidade presencial. Já em Rio Claro eram 203 alunos, sendo 150 nos anos finais do ensino fundamental e 53 no ensino médio na modalidade presencial. 
Itaguaí foi o único município da região que possuía uma escola estadual rural com 30 alunos matriculados nos anos finais do ensino fundamental e 61 no ensino médio na modalidade presencial.

Quanto às escolas municipais, existiam 49 escolas na região com turmas de educação de jovens e adultos, sendo: 15 em Angra dos Reis, 13 em Itaguaí, 12 em Parati, 6 em Mangaratiba e 3 em Rio Claro.

Em Angra dos Reis, estavam matriculados 1.440 alunos, sendo 380 nos anos iniciais do ensino fundamental e 1.060 nos anos finais. Já em Itaguaí, 1.563 alunos, sendo 400 nos anos iniciais do ensino fundamental e 1.163 nos anos finais. O Município também possuía 185 alunos matriculados nos anos finais do ensino fundamental na modalidade semipresencial.

Em Mangaratiba, estavam matriculados 654 alunos, sendo 91 nos anos iniciais do ensino fundamental e 563 nos anos finais. O Município possuía 235 alunos matriculados nos anos finais do ensino fundamental na modalidade semipresencial.

Em Parati, estavam matriculados 495 alunos, sendo 56 nos anos iniciais do ensino fundamental e 439 nos anos finais. Já em Rio Claro estavam matriculados 45 alunos nos anos iniciais do ensino fundamental.

Nas escolas privadas da região, estavam matriculados 649 alunos nos municípios de Angra dos Reis, Itaguaí e Parati na EJA, sendo: 364 em Angra dos Reis ( 87 nos anos iniciais do ensino fundamental e 277 no ensino médio) e 21 no ensino médio semipresencial; 216 alunos no ensino médio presencial integrado a formação profissional em Itaguaí; e 69 alunos em Parati (19 nos anos iniciais do ensino fundamental e 50 no ensino médio).

Com relação ao quadro de professores, em 2011, a rede municipal de Angra dos Reis possuía 1.143 professores, todos do quadro efetivo. Mangaratiba, 943 , sendo 670 efetivos $(71,04)$ e 273 contratados (28,95\%). Parati, 418 professores, sendo 300 efetivos $(71,77 \%)$ e 118 contratados (28,22\%). Rio Claro, 253 , sendo 203 efetivos $(80,23 \%)$ e 50 contratados (19,76\%). Itaguaí não informou.

Atuando na educação de jovens e adultos, Angra dos Reis possuía 197 professores; Itaguaí 105; Mangaratiba 86; Parati 33 e Rio Claro 8 professores.

Quanto ao perfil dos 428 professores de EJA que atuavam na região, em 2011, 382 eram efetivos e 46 contratados. A maioria dos contratados na EJA estava em Itaguaí, 29 professores. 
Com relação a sua formação, 156 eram professores com formação apenas de ensino médio; 356 com ensino superior; 65 com curso de especialização; 12 com mestrado e 3 com doutorado.

Angra dos Reis é o município que concentrava o maior número de professores com formação de ensino superior (167), com especialização (46), com mestrado (11) e doutorado (2).

Quanto à formação dos seus professores, somente os municípios de Angra dos Reis, Parati e Rio Claro informaram existir alguma exigência para o profissional iniciar o trabalho na EJA. No mínimo, formação de professores no ensino médio.

Com relação a uma proposta de formação continuada para os seus professores que atuam na EJA, com exceção de Rio Claro, os demais municípios possuem projetos. Rio Claro informou que previa para 2013, com a organização da Divisão de EJA, uma proposta de formação para os professores da EJA. Em Parati são realizadas reuniões periódicas com os professores para discutir os projetos e trocar experiências. Segundo a coordenação de EJA, "é um momento de análise, discussão e reflexão, possibilitando ao professor redirecionar o seu trabalho e auxiliar a sua prática pedagógica".

Em Angra dos Reis estava previsto no seu calendário anual os eventos "Encontros de EJA" e o "Fórum de Alfabetização de Jovens, adultos e idosos", além da realização de oficinas pedagógicas. Eram realizadas "coordenações periódicas com o grupo de professores e coordenadores da Secretaria”. Em parceria com o Instituto de Educação de Angra dos Reis da Universidade Federal Fluminense (IEAR/UFF), foi realizado, em 2011, o curso de extensão para os professores e organizaram palestras para os professores nos seus "Encontros".

Itaguaí realizava "Oficinas Pedagógicas" para os professores. Segundo a sua coordenação, são organizados "Encontros Pedagógicos" bimestrais para coordenadores pedagógicos das unidades escolares e professores.

Em Mangaratiba, além de encontros pedagógicos, no período de 2011 e 2012 foram realizados, em parceria com o IEAR/UFF, o Colóquio de EJA. No primeiro semestre de 2012, também em parceria com o Instituto, foi realizado o primeiro curso de extensão para os professores de EJA.

Todos os municípios informaram não existir um "plano de cargos e salários" específicos para os professores que atuam na EJA, mas sim para todos os professores que atuam na Rede. 
Angra dos Reis informou que, enquanto coordenação de EJA, "na medida do possível, procura manter a matrícula do professor de EJA, evitando complementação de carga horária nessa modalidade".

Além das experiências de escolarização previstas na Lei de Diretrizes e Bases da educação, na região temos experiências diversas de cursos de qualificação e formação profissional não oferecidas com certa regularidade por instituições da sociedade civil, principalmente por Organizações Não Governamentais (ONG) e sindicatos.

Em Angra dos Reis e Itaguaí, além destas experiências, contam com a presença de campi do Centro Federal de Educação Tecnológica Celso Suckow da Fonseca (CEFET/RJ) e de unidades do Serviço Nacional de Aprendizagem Industrial (SENAI) e do Serviço Nacional de Aprendizagem Comercial (SENAC).

Desde 2010, com a criação do Fórum Regional Sul Fluminense de Educação de Jovens e Adultos, vem se realizando reuniões periódicas com a participação de gestores das secretarias municipais, representantes dos conselhos municipais de educação, professores da rede municipal da região Costa Verde e professores do Instituto de Educação de Angra dos Reis.

Além dos encontros para discussão de temas de interesse sobre a educação de jovens e adultos, o Fórum Regional Sul Fluminense de Educação de Jovens e Adultos organizou o Seminário Regional de Educação de Jovens e Adultos em 2012.

Analisando a experiência apresentada por cada Secretaria Municipal de Educação foi possível evidenciar ausência na institucionalização das práticas políticas, administrativas e pedagógicas na implementação da EJA na Região. As próprias experiências consideradas exitosas nacionalmente, como as condecoradas com a Medalha Paulo Freire, por exemplo, não se sustentaram ao longo dos anos, permanecendo apenas como projetos.

Embora seja reconhecido a EJA nos marcos legais como modalidade da educação básica no sistema nacional de ensino, inclusive com previsão orçamentária de recursos via FUNDEB, nenhum município da Região apresentou concretamente os investimentos na área. Algumas secretarias chegaram afirmar não apresentar de forma detalhada no seu "Planejamento Orçamentário" a distribuição dos recursos para a rede, apenas especificam as rubricas gerais como alimentação, transporte, material, pessoal etc. Segunda elas, o aluno da EJA é visto como qualquer aluno, sem qualquer distinção. 
Por outro lado, a prática de não previsão orçamentária de recursos específicos para EJA pode também não deixar claro a sua ausência. Ou seja, em muitas escolas não são garantidos direitos básicos para os alunos da EJA como merenda, material didático, transporte etc.

Sobre a participação dos Conselhos Municipais de Educação na implementação da política de EJA na região, em um primeiro momento, fomos informados pela Coordenação Regional Sul-Fluminense da União dos Conselhos Municipais de Educação (UNCME), que cada conselho tem autonomia para desenvolver as suas atividades. Segundo a coordenadora, em 2012, a atenção dos Conselhos na região estava naquele momento para as ações referentes a educação infantil.

Por conta da realização da pesquisa e criação do Fórum Regional Sul Fluminense de Educação de Jovens e Adultos, os conselhos passaram a ter um maior interesse pelo tema, inclusive promovendo debates para os conselheiros municipais.

Em agosto de 2013, por conta das discussões implementadas junto aos Conselhos Municipais na região sobre EJA, a União dos Conselhos Municipais de Educação do Estado do Rio de Janeiro (UNCME/RJ), incluíram na sua Programação do XII Encontro Estadual, uma mesa sobre Educação de Jovens e Adultos.

Gráfico 3: Censo escolar educação de jovens e adultos (Ensino Fundamental) Região Costa Verde ${ }^{14}$

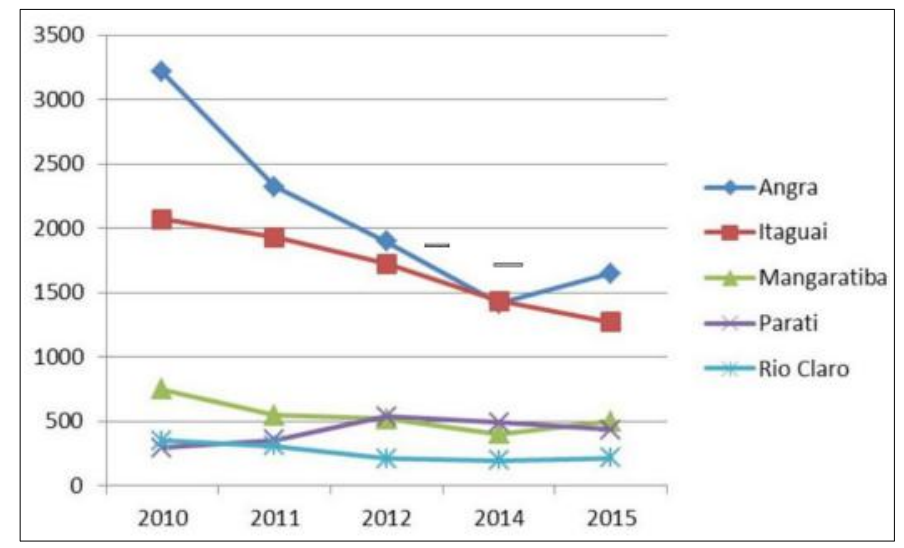

Fonte: INEP (2010 - 2015)

14 Os dados de 2013 não foram utilizados, pois eram muito baixos e apresentavam inconsistências. 
Conforme gráfico 3, é possível evidenciar, assim como ocorre em todo o Brasil, um decréscimo frequente no número de matrículas na região nos últimos 5 anos. Registrou uma queda de 39,14\%, saindo de 6.683, em 2010, para 4.067, em 2015.

Com relação ao Ensino Fundamental, Angra dos Reis saiu de 2.216 matrículas, em 2010, para 1.648, em 2015, representando uma queda de 25,63\% em 5 anos. Em Itaguaí, a queda foi de 38,67\%, saindo de 2.071, em 2010, para 1.270, em 2015. Em Mangaratiba, foi de 33,24\%, saindo de 749 para 500, em 2015. Em Rio Claro, a queda nas matrículas foi de 39,20\%, saindo de 352 para 214, em 2015.

Em Parati, ao contrário dos demais municípios, houve um crescimento de 47,45\%, saltando de 295, em 2010, para 435, em 2015.

Quanto ao Ensino Médio, analisando 2014 e 2015, com exceção de Rio Claro e Mangaratiba, que houve uma redução de matrículas na EJA, caindo de 53 para 47 (Rio Claro) e de 216 para 200 (em Mangaratiba), em Angra dos Reis houve um aumento de 18,51\% (537 em 2014 para 659 em 2015); em Itaguaí de 26,01\% (219 para 296); e em Parati de 23,76\% (77 para 101).

Em uma análise geral da organização dos sistemas municipais de ensino da região pesquisada, foi possível evidenciar a ausência de Projetos Políticos Institucionais (PPI) nas Secretarias Municipais de Educação. Por isso se justificam a ausência de dados consolidados sobre a demanda para a política implementada; de planejamento a médio e longo prazos; de acompanhamento, monitoramento e avaliação das ações, gerando projetos de governo de caráter pontual, fragmentado e descontínuo.

\section{Considerações Finais}

Durante muitos anos, quando se falava em educação para jovens e adultos, imaginava-se estar falando de um grupo social homogêneo com características biopsicossociais bem distintas e definidas. Não se levava em consideração as suas particularidades, especificidades, tão pouco a sua diversidade: faixa etária; sexo; raça; credo religioso; ocupação profissional; opção sexual; situação social (privados ou não de liberdade) etc.

Com os avanços instituídos na área nos últimos anos, principalmente no âmbito do reconhecimento do direito humano fundamental em que se constitui a Educação em seu papel na sociedade contemporânea, a necessidade de compreensão dessas particularidades, para se levar em consideração as propos- 
tas político-pedagógicas, traz como primordial a compreensão sobre os sujeitos da EJA. Cresce o número de estudos e de discussões que visam, mergulhados nesse contexto, responder às seguintes questões: quem são tais sujeitos? De onde vêm? Para onde vão? Qual a sua verdadeira identidade? Quais são os seus reais interesses e expectativas?

$\mathrm{Na}$ busca pela compreensão dos atuais sujeitos da EJA, passamos a identificar que estamos falando de um campo muito diverso, com muitas particularidades, especificidades e armadilhas. Hoje, principalmente, necessitamos compreender melhor essa modalidade de ensino diante da diversidade do público, levando em consideração inclusive as suas características no território.

Neste sentido, a proposta política que privilegiava a constituição de Agenda Territorial de Desenvolvimento Integrado de Alfabetização e de Educação de Jovens e Adultos representou um importante marco nesta direção, visto que vislumbrava possibilitar melhor compreensão dos dados hoje dispersos em estados, regiões, municípios, bairros e comunidades.

Analisando as experiências de políticas públicas implementadas para a educação de jovens e adultos na Região Costa Verde do estado do Rio de Janeiro, foi possível evidenciar que os seus problemas não diferem das demais experiências brasileiras que vão deste a compreensão do papel da educação para jovens e adultos até a sua proposta política pedagógica que não leva em consideração a realidade dos sujeitos no seu território.

Neste sentido, defendemos que além da necessidade de compreensão das características sócio, econômica, político e cultural do território é fundamental que se leve em consideração o perfil de cada sujeito que demanda a política. Não podemos simplesmente defender a garantia de direito à educação, mas que também, além de primar por uma qualidade social da educação, esteja fundamentada nos princípios constitucionais que visam "o pleno desenvolvimento da pessoa, seu preparo para o exercício da cidadania e sua qualificação para o trabalho" (Brasil, 2015, Art. 205 da CF).

A EJA não pode continuar sendo ações pontuais, meros projetos de governo, mas sim ser reconhecida como política estratégica para o desenvolvimento humano, social e político regional.

Compreendendo que a diversidade deve ser entendida como uma construção histórica, cultural, social e econômica das diferenças, analisando os documentos finais do CONEB (2008) e do CONAE (2010; 2014) emergem reflexões importantes que nos ajudam a pensar sobre as atuais discussões na área de EJA. Os documentos nos chamam a atenção para o consenso na educação bra- 
sileira acerca da necessidade da inclusão, sobretudo quando se observa o caráter excludente da sociedade e suas repercussões na garantia dos direitos sociais e humanos, porém, para compreender, agir e garantir a diversidade, são necessários posicionamentos, práticas políticas e o entendimento da relação entre inclusão, exclusão e diversidade, articulados a uma visão ampla de educação e desenvolvimento sustentável; que a política de inclusão que contemple as diferenças vai além do aspecto social, trata-se de noção mais ampla e politizada de inclusão que tem como eixo o direito ao trato democrático e público da diversidade em contextos marcados pela desigualdade e exclusão social; e que as políticas educacionais devem se estruturar de forma a contribuir na discussão da relação entre formação, diversidade, inclusão e qualidade social da educação básica.

Nesse sentido, é fundamental problematizar questões como a contextualização curricular e formação profissional a partir da diversidade regional. Ao pensar em políticas públicas que concorram para a inclusão, há que se garantir que tais políticas reconheçam o direito à diversidade, sem opor-se à luta pela superação das desigualdades sociais; que se tenha clareza sobre a concepção de educação que proporcione a inclusão de todos no processo educacional de qualidade; que politizem as diferenças e as coloquem no cerne das lutas pela afirmação dos direitos; e que se invista em uma política de educação para o desenvolvimento sustentável que respeite o sujeito e a natureza.

Alguns problemas evidenciados no território da Região Costa Verde não são diferentes dos que estão acontecendo em todo o Brasil, principalmente destacando a ausência de um currículo, proposta pedagógica, recursos e de formação inicial e continuada de docentes e equipe técnica responsável pela política de EJA adequados para a realidade local.

A compreensão errônea do que significa a EJA como modalidade de educação básica, por exemplo, tem significado uma proposta político-pedagógica que reproduz uma adaptação da proposta de ensino regular, prevista para crianças, para jovens e adultos. Na maioria das vezes, além da redução de conteúdos previstos no ensino regular, as propostas pedagógicas para a EJA estão distantes da realidade dos sujeitos, gerando empobrecimento do currículo e infantilização pedagógica.

Por não existir um Projeto Político Institucional das Secretarias de Educação e ausência na institucionalização das práticas políticas, administrativas e pedagógicas na implementação da EJA na Região, fica muito difícil compreender as particularidades regionais e construir um sistema de ensino fundamentado e adequado a sua realidade. 
Com o distanciamento da proposta político pedagógica dos sujeitos, automaticamente reduz-se as matrículas na modalidade, consequentemente, diminui-se o número de turmas e de escolas que oferecem turmas para a EJA. Assim não é difícil identificar os motivos que hoje justificam o desmantelamento da política de EJA no Brasil.

Embora a região seja rica na diversidade de instituições que desenvolvem ações para educação de jovens e adultos, como organizações diversas da sociedade civil organizada, CEFET, SENAI, SENAC e Universidade Federal Fluminense (UFF), infelizmente, ainda não atuam em uma rede consolidada. Em raríssimos momentos, evidenciam-se projetos articulados e/ou com a participação direta do poder público local.

Levando em conta a existência no município de Angra dos Reis de uma unidade do Centro Federal de Educação Tecnológica Celso Suckow da Fonseca (CEFET/RJ), por exemplo, a Secretaria municipal de educação tentou, em 2014, sem sucesso, a implementação do Programa Nacional de Integração da Educação Básica Profissional com a Educação na Modalidade de Educação de Jovens e Adultos (PROEJA). Embora a Secretaria Municipal tenha se mobilizado, propondo uma parceria que envolveria inclusive a Universidade Federal Fluminense, através da sua unidade de Angra dos Reis - Instituto de Educação de Angra dos Reis, para a capacitação dos profissionais para atuar no Programa, o CEFET mostrou-se, no momento, desinteressado na proposta.

Desde 2010, com a criação da unidade da UFF - Instituto de Educação de Angra dos Reis (IEAR), são realizadas ações de formação inicial e continuada de profissionais, através de disciplinas no curso de graduação em Pedagogia, de cursos de curta duração e eventos de extensão sobre a educação de jovens e adultos para os profissionais da região, assim como com a realização de pesquisas (como esta) e de acompanhamento de estagiários na realização das suas atividades de campo no primeiro segmento do ensino fundamental nas escolas públicas da região.

A criação do Fórum Regional Sul-Fluminense de EJA, em 2011, representa uma importante iniciativa de promover a constituição de uma rede local de socialização de experiências e de mobilização dos profissionais, dos representantes políticos e das diversas instituições governamentais e não governamentais interessadas no tema e de empoderamento da rede local. Infelizmente, como toda iniciativa da sociedade civil, tem sofrido com a descontinuidade, principalmente dos representantes governamentais, e de ausência de recursos para implementação das suas ações. 
Como uma iniciativa voluntária, depende exclusivamente do apoio personalizado de alguns sujeitos locais. A sua ausência, por motivos diversos, ocasiona descontinuidade nas ações previstas.

Enquanto o Fórum não for reconhecido como um espaço público e de interesse público, a sua continuidade está ameaçada.

Estamos vivendo um dos momentos mais críticos da história da nossa democracia. O golpe parlamentar e empresarial que aprovou o injustificado impeachment em agosto de 2016 orquestrado por uma parte da sociedade conservadora (e apoiado por instituições que se afirmam republicana) põe em risco conquistas históricas das classes populares e trabalhadora.

Os últimos acontecimentos no país - destacando-se o resultado das últimas eleições em várias capitais do Brasil, principalmente em São Paulo e Rio de Janeiro e a ameaça da aprovação no Congresso de projetos de lei que violam a nossa constituição e escancaram a nossa economia para o capital externo abrem cicatrizes que vulnerabilizam a nossa cidadania.

Diante da histórica crise política, econômica, institucional e ética que vivemos no Brasil, temo pelo nosso futuro e por todas as conquistas políticas, econômicas e sociais das classes populares da última década. Lamento que estejamos assumindo a cultura de direita que acredita e defende a ideia de direitos do EU e direitos dos OUTROS em detrimento de direitos de TODOS.

Com o avanço e consolidação da cultura de direita no mundo, os últimos acontecimentos têm representado um duro golpe nas forças progressistas e democráticas, fortalecendo cada vez mais o discurso conservador apolítico, machista, homofóbico, sexista etc. que não reconhece o "direito de ser igual quando a diferença nos inferioriza e o direito de ser diferente quando a igualdade nos descaracteriza" (Santos, 2003, p. 56).

Sem sombra de dúvida, o campo progressista tem agora (mais do que nunca) o desafio de mobilizar os movimentos sociais, as centrais sindicais e a população em geral em torno de uma possível "frente progressista" em luta por um horizonte menos nebuloso para as futuras gerações.

Não podemos simplesmente aguardar que o tempo dê conta de curar as cicatrizes. Precisamos nos reorganizar e nos reconstruir a partir dos nossos próprios escombros. Precisamos seguir unidos defendendo "nenhum direito a menos" para todos, principalmente recuperando horizontes políticos que foram iniciados em 2003 e da Agenda Territorial de Desenvolvimento Integrado de Alfabetização e de Educação de Jovens e Adultos (2007). 


\section{Referências}

BALL, S.; MAINARDES, J. (org.). Políticas Educacionais: questões e dilemas. São Paulo: Cortez, 2011.

BRASIL. Constituição (1988). Constituição da República Federativa do Brasil. Brasília, DF: Senado Federal, 2015.

. Lei no 13.005 de 25 de junho de 2014. Aprova o Plano Nacional de Educação (2014 - 2024). Brasília, DF. Diário Oficial da União - Seção 1 - Edição Extra - 26/6/2014, Página 1 (Publicação Original)

Conferência Nacional de Educação (CONAE). Ministério da Educação. Distrito Federal: 2014.

Conferências Nacionais de Educação: construindo o sistema nacional articulado de educação - o Plano Nacional de Educação, Diretrizes e Estratégias de Ação (Documento final). Brasília, DF: MEC, 2010.

. Lei 9394/1996. Lei de Diretrizes e Bases da Educação. Brasília, DF. Diário Oficial da União - Seção 1 - 23/12/1996, Página 27833 (Publicação Original)

Agenda Territorial de Desenvolvimento Integrado de Alfabetização e de Educação de Jovens e Adultos. Brasília, DF: Ministério da Educação/SECAD, 2008.

. Conselho Nacional de Educação. Resolução CNE/CEB n ${ }^{\circ} 1$ de

2000. Dispõe sobre as Diretrizes Curriculares Nacionais para a Educação de Jovens e Adultos. Brasília, DF: CNE, 2000.

. Conselho Nacional de Educação. Resolução CNE/CEB no 3 de

2010. Dispõe sobre Diretrizes Operacionais para a Educação de Jovens e Adultos nos aspectos relativos à duração dos cursos e idade mínima para ingresso nos cursos de EJA; idade mínima e certificação nos exames de EJA; educação de Jovens e Adultos desenvolvida por meio da Educação a Distância. Brasília, DF: CNE, 2010.

HAESBAERT, R. O mito da desterritorialização: do fim dos "territórios" à multiterritorialidade. Rio de Janeiro: Bertrand Brasil, 2004.

IBGE. Pesquisa Nacional por Amostragem dos Domicílios (PNAD). Brasília, DF: Instituto Brasileiro de Geografia e Estatística (IBGE), 2009. 
Censo 2010. Brasília, DF: Instituto Brasileiro de Geografia e Estatística (IBGE), 2010.

Síntese dos Indicadores Sociais: uma análise das condições de vida da população brasileira 2012. Rio de Janeiro: IBGE, 2012

INEP. Censo Escolar 2013. Brasília, DF: Instituto Nacional de Estudos e Pesquisas Educacionais Anísio Teixeira, 2014.

Censo Escolar 2014. Brasília, DF: Instituto Nacional de Estudos e Pesquisas Educacionais Anísio Teixeira, 2015.

Censo Escolar 2015. Brasília, DF: Instituto Nacional de Estudos e Pesquisas Educacionais Anísio Teixeira, 2016.

JULIÃO, E. F. A diversidade dos sujeitos da educação de jovens e adultos. In: MEDEIROS, C. C; GASPARELLO, A; BARBOSA, J. L. Educação de jovens, adultos e idosos: saberes, sujeitos e práticas. Niterói: UFF/Cead, 2015, p. $157-$ 170.

MACHADO, M. M. A educação de jovens e adultos no Brasil pós-Lei 9.394/96: a possibilidade de constituir-se como política pública. Educação de Jovens e Adultos, Brasília, v. 22, n. 82, p. 17-39, nov. 2009.

MARINHO, L. M. H. de M. Entre nós e encruzilhadas: as trajetórias dos jovens de 15 a 17 anos na EJA em Angra dos Reis. 2015. fls. 160 . Dissertação 0 Programa de Pós-graduação em Educação, Universidade Federal Fluminense, Niterói, 2015.

ORTIZ, R. Universalismo e Diversidade. São Paulo: Biotempo, 2015.

RIO DE JANEIRO. Lei complementar nº 105, de 04 de julho de 2002. Altera a Lei complementar $\mathrm{n}^{\circ} .87$, de 16 de dezembro de 1997, com a nova redação dada pela lei complementar $n^{\circ} .97$, de 02 de outubro de 2001, e a Lei complementar $n^{\circ} .89$, de 17 de julho de 1998, e dá outras providências, na forma que menciona. Rio de Janeiro: ALERJ, 2002.

. Secretaria de Estado de Educação - SEEDUC. SEEDUC em números: transparência na educação. Rio de Janeiro, SEEDUC: 2012.

. Secretaria de Estado de Educação - SEEDUC. SEEDUC em números: transparência na educação. Rio de Janeiro, SEEDUC: 2013 .

. Secretaria de Estado de Educação - SEEDUC. SEEDUC em números: transparência na educação. Rio de Janeiro, SEEDUC: 2014. 

. Tribunal de Contas do Estado do Rio de Janeiro. Estudos Socioeconômicos dos Municípios do Estado do Rio de Janeiro do Tribunal de Contas do Estado do Rio de Janeiro (Angra dos Reis, Itaguaí, Mangaratiba, Parati e Rio Claro). Rio de Janeiro, Tribunal de Contas do Estado do Rio de Janeiro: 2014.

. Lei de Responsabilidade Educacional - Relatório 2015. Rio de Janeiro, SEEDUC: 2015.

SANTOS, B. de S. Reconhecer para libertar: os caminhos do cosmopolitanismo multicultural. Rio de Janeiro: Civilização Brasileira, 2003.

SAQUET, M. A. Abordagens e concepções sobre o território. 3. ed. São Paulo: Outras expressões, 2013

SENNETTT, R. A corrosão do caráter: as consequências pessoais do trabalho no novo capitalismo. Rio de Janeiro: Record, 1999.

SEN, A. Desenvolvimento como liberdade. São Paulo: Companhia das Letras, 2010.

SOUZA, M. J. L. de. O território: sobre o espaço e o poder, autonomia e desenvolvimento. In: CASTRO, I. E. de; GOMES, P. C. da C.; CORREA, R. L. Geografia: Conceitos e temas. Rio de Janeiro: Bertrand Brasil, 1995. 
